\title{
Production and Characterization of Rice Husk Biosorbent from Far North Cameroon
}

\author{
Elie Kolwa Doboy ${ }^{2}$, Henriette Zangue Adjia ${ }^{1,2} \&$ Richard Kamga ${ }^{2}$ \\ ${ }^{1}$ Laboratoire Interdisciplinaire des Environnements Continentaux (LIEC) UMR 7360, CNRS, Universite de \\ Lorraine, France \\ ${ }^{2}$ National School of Agro-Industrial Sciences (ENSAI), University of Ngaoundere, Adamaoua, Cameroon \\ Correspondence: Henriette Zangue Adjia, University of Ngaoundere, P.O Box: 455 Adamawa, Cameroon. Tel: \\ 237-6-9959-6578. E-mail: hzangue42@gmail.com
}

Received: July 20, $2019 \quad$ Accepted: August 29, $2019 \quad$ Online Published: September 3, 2019

doi:10.5539/ep.v8n2p1 URL: https://doi.org/10.5539/ep.v8n2p1

\begin{abstract}
The objective of this study is the production and the characterization of rice husk biosorbent. In fact, the biosorbent has been obtained by phosphoric acid treatment; its physicochemicals characteristics such as point of zero charge, specific surface, iodine number and chemicals functions have been determined. The analysis indicaded that, the point of zero charge is 8.7 ; for the $\mathrm{pH}$ value less than 8.7 , the biosorbent surface is posotively charged and for $\mathrm{pH}$ value higher than 8.7 , the biosorbent surface is negatively charged. The biosorbent iodine number is $1560.87 \pm 1 \mathrm{mg} / \mathrm{g}$, it means that, the biosorbent is constituted in majority of microspores. Furthermore, the specific surface of biosorbent is $104.45 \pm 1 \mathrm{~m}^{2} / \mathrm{g}$, it is five times as big than untreated rice husk obtained by Dada and al., (2012). Acid treatment improve the porosity of biosorbent. Infrarouge spectrum present ether and aromatic functions.
\end{abstract}

Keywords: rice husk, biosorbent, by phosphoric acid treatment, characterisation, Far north-Cameroon

\section{Introduction}

Activated carbon is the most adsorbent used in adsorption process due to it extend surface area, its microporous structure and its high adsorption capacity. However, its higher cost specializes the research to low costs adsorbents. Different biomass has been test as low-cost adsorbent (Özacar et Sengil, 2005; Saeed et al, 2005; Ho, 2005; Kumar et Kumaran, 2005; Franca et al., 2008; Dàvila-Jimenez et al., 2009; Dada et al., 2012; Tchuifon, 2016, Eko, 2016; Mouthe, 2017). In the Far North Region of Cameroon, important quantities of rice husk (60000 tonnes) are product each year. These waste solids provided from rice growing practice in that Region and represent $20 \%$ of the whole rice (Daifullah et al., 2003). In spite of their abundance, these rice husks are abandoned in the nature and polluted the environment. The advantages of the use of these waste solids are:

* The valorization of agro resources which are available, and low cost;

* The positive repercussions of activated carbon cost;

* The creation of geriatric activities jobs;

* The protection of environment.

The aim of this study is the production of rice husk biosorbent from far north Cameroon to eliminate pollutants from waste water. Specifically we will :

$>$ Product rice husk biosorbent;

$>$ Determine physicochemicals characteristics of biosorbent.

\section{Material and Methods}

\subsection{Material}

The material used in the production of biosorbent is essentially constitued by rice husk. They have been collected from non-control site discharge of Yagoua, Department of Mayo Danay, Far North Region of Cameroon (Figure 1). (Latitude $10^{\circ} 20^{\prime} 27 \mathrm{~N}$; Longitude $15^{\circ} 13^{\prime} 58 \mathrm{E}$ ). These waste solids represented in Figure 1 where obtained after the shelling of rice. 


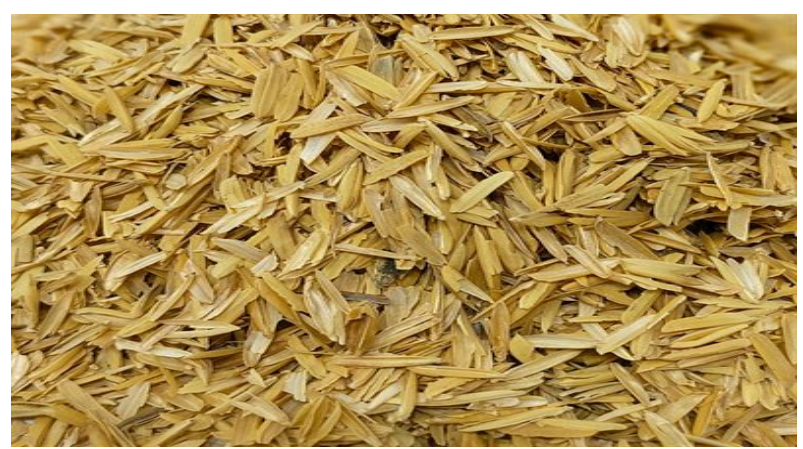

Figure 1. Rice husk (Kolwa, Yagoua-Far north Cameroon, march 2018)

\subsection{Methods}

\subsubsection{Preparation of Biosorbent}

Rice husk have been soaked in distilled water for about 4 hours and washed in other to eliminate impurities and suspension particles. Then they have been oven dried at $50^{\circ} \mathrm{C}$ for 24 hours then immersed in phosphoric acid $1 \mathrm{M}$ for 24 hours. The mixing has been filtered and washed with distilled water until neutral $\mathrm{pH}$. The residual obtained has been oven dried at $105^{\circ} \mathrm{C}$ until constant weights. Finally, active rice husk has been crushed and sifted in other to obtain a granulometry less than $500 \mu \mathrm{m}$. The biosorbent obtained has been conserved in closed jar. The figure 2 presents the process of the production of rice husk biosorbent.

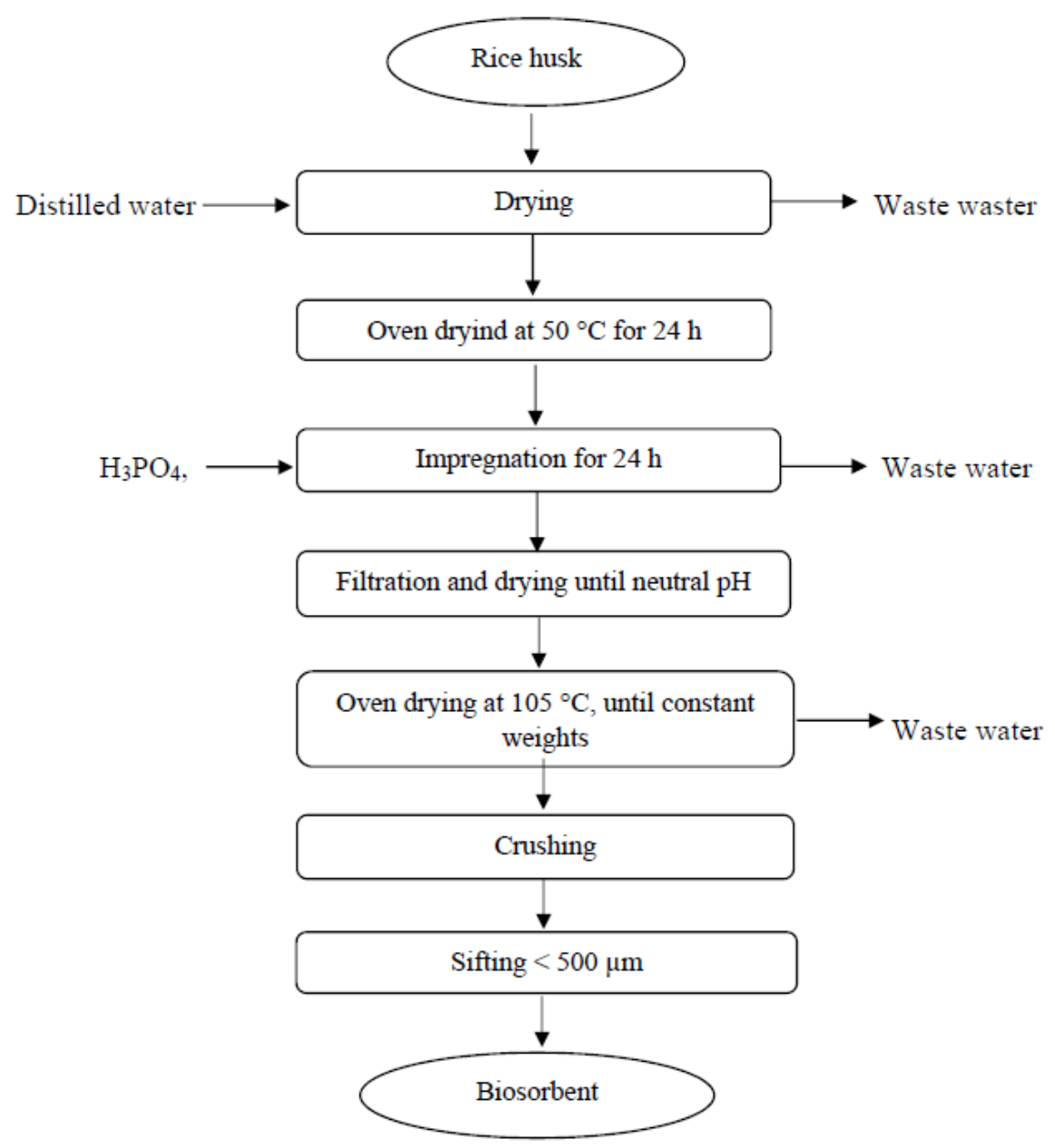

Figure 2. Process of the production rice husk biosorbent 


\subsubsection{Characterization of Biosorbent}

\subsubsection{Determination of Zero Point Charge $\left(\mathrm{pH}_{\mathrm{pzc}}\right)$}

The point of zero charge $\left(\mathrm{pH}_{\mathrm{pzc}}\right)$ is the $\mathrm{pH}$ which total charges at solid surface is null. The method describes by Faria et al., (2004) has been used to determine the $\mathrm{pH}_{\mathrm{pzc}}$ of biosorbent products. This method consists to measure the variation of $\mathrm{pH}$ when a solution of chlorhydric acid $(0,01 \mathrm{M})$ or soda $(0,01 \mathrm{M})$, to $50 \mathrm{ml}$ of a solution $\mathrm{NaCl}$ $(0,01 \mathrm{M})$ container $0,05 \mathrm{~g}$ of biosorbent at $25^{\circ} \mathrm{C}$. When the $\mathrm{pH}$ of $\mathrm{NaCl}$ solution is set, we add $0,05 \mathrm{~g}$ of biosorbent. The hole is shaking for $24 \mathrm{~h}$, and the final $\mathrm{pH}$ is written down. We have represented $\Delta \mathrm{pH}=\mathrm{f}$ (pHi) where $\Delta \mathrm{pH}=$ (pHf-pHi). The intersection point between the curve and the strainght line $\mathrm{x}=0$ corresponding to $\mathrm{pHpzc}$ of biosorbent.

\subsubsection{Determination of Specific Surface by Blue Methylene Method}

The principle of the method consists to determine the adsorption capacity of biosorbent by measuring the quantity of Blue Methylene (BM) necessary to cover total surface, of all clayey particules presents in the solution by a monolayer of blue methylene.

The mass of $1 \mathrm{~g}$ of biosorbent has been mixed in $100 \mathrm{ml}$ beaker with $20 \mathrm{ml}$ of distilled water and shook for 5 minutes at $700 \mathrm{trs} / \mathrm{min}$ by magnetic agitator. After, we add with gradual burette, $5 \mathrm{ml}$ of Blue Methylene $(10 \mathrm{~g} / \mathrm{L})$, the mixture is shaken at $400 \mathrm{trs} / \mathrm{min}$ during one minute. With the glass stick, we take one drop of solution that we filter with wattman paper. The test is «positive» if on filter paper, we have a blue central drop surrounded by a blue humid zone. The test is " negative " if the blue central drop is surrounded by an incolore humid zone (AFNOR, 1996). If the test is " positive », we add every one minute, $1 \mathrm{ml}$ of BM for about 5 times to confirm the result. But if the test is «negative », we add $5 \mathrm{ml}$ of BM until we obtain the «positive » test. After obtaining the «positive » test, we note the volume of BM corresponding and we determine the value of the Blue Methylene of biosorbent (VBS) with the formula:

$$
\mathrm{VBS}=\frac{\mathrm{v}}{\mathrm{m}} \times 100
$$

Where $\mathbf{v}$ is the volume of BM adsorbed (ml) corresponding to the « positive » test; $\mathrm{m}$ the mass of biosorbent. To determine the value of specific surface (SS) we use the formula:

$$
\mathrm{SS}=\mathrm{VBS} \times 20,93
$$

\subsection{Evaluation of Porosity}

Iodine number is an indicator of biosorbent porosity because it measures the porosity of biosorbent. Iodine number is defined as a number of milligramme of iodine adsorped by $1 \mathrm{~g}$ of adsorbent (Calvet, 1980). In fact, in erlenmeyer $50 \mathrm{ml}$, we introduice $0.05 \mathrm{~g}$ of biosorbent and $10 \mathrm{ml}$ of iodine solution $0.1 \mathrm{~N}$. We add to the mixture, 2 drops of starch emporium as color indicator. We add drop by drop from burette, $0.1 \mathrm{~N}$ thiosulfate sodium solution (Faouzia, 2010). The iodine number is determined by formula:

$$
I d=\frac{\left(V_{b}-V_{s}\right) \cdot N \cdot 1 \cdot 5 M_{I}}{m}
$$

Where : $\left(\mathrm{V}_{\mathrm{b}}-\mathrm{Vs}\right)$ is the difference between results of test without biosorbent and the test with biosorbent ( $\mathrm{ml}$ of sodium thiosulfate $0,1 \mathrm{~N}) ; \mathrm{N}$, normality of sodium thiosulfate solution $(\mathrm{mol} / \mathrm{L}) ; \mathrm{M}_{\mathrm{I}}$, Molar mass of iodine $(126,9 \mathrm{~g} / \mathrm{mol}) ; \mathrm{m}$, the mass of biosorbent $(\mathrm{g})$.

\subsection{Fourier Transform Infrared Spectroscopy (FTIR)}

Infrared spectra were recorded using an IFS 55 Bruker Fourier transform IR spectrometer equipped with an MCT detector (4000 to $500 \mathrm{~cm}^{-1}$ ) cooled a $77 \mathrm{~K}$ and in diffuse reflectance (Harrick attachment) mode. The amount of clay was $70 \mathrm{mg}$ dispersed in $370 \mathrm{mg} \mathrm{KBr}$.

\section{Results and Discussion}

\subsection{Production of Biosorbent}

The Figure 3 presents the biosorbent producted. Rice husk have the good appearance and granulometry as low cost adsorbent for growing country. The rice husk as pollutants is easy to be transformed like biosorbent to clean waste water. 


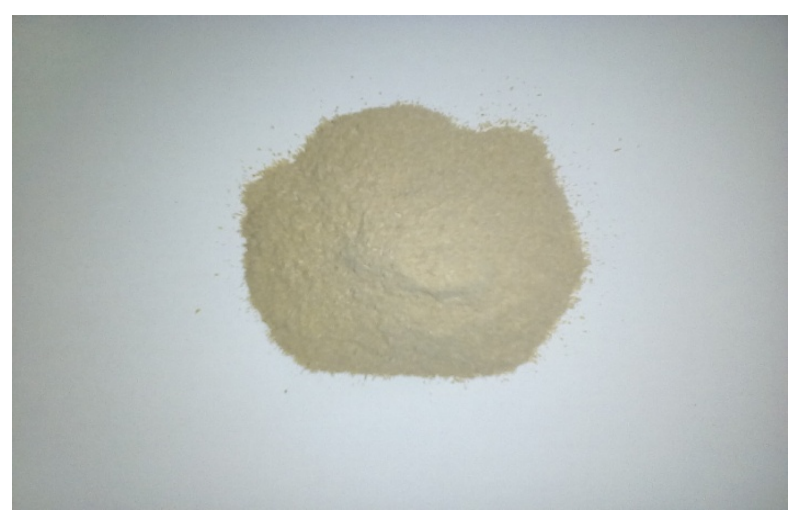

Figure 3. Rice husk biosorbent

\subsection{Physico-Chemical Characterization of Biosorbent}

\subsubsection{Point of Zero Charge of Biosorbent}

The point of charge $\left(\mathrm{pH}_{\mathrm{PZC}}\right)$ is the intersection point between the curve and the straight-line $\mathrm{x}=0$. It value is 8.7 .

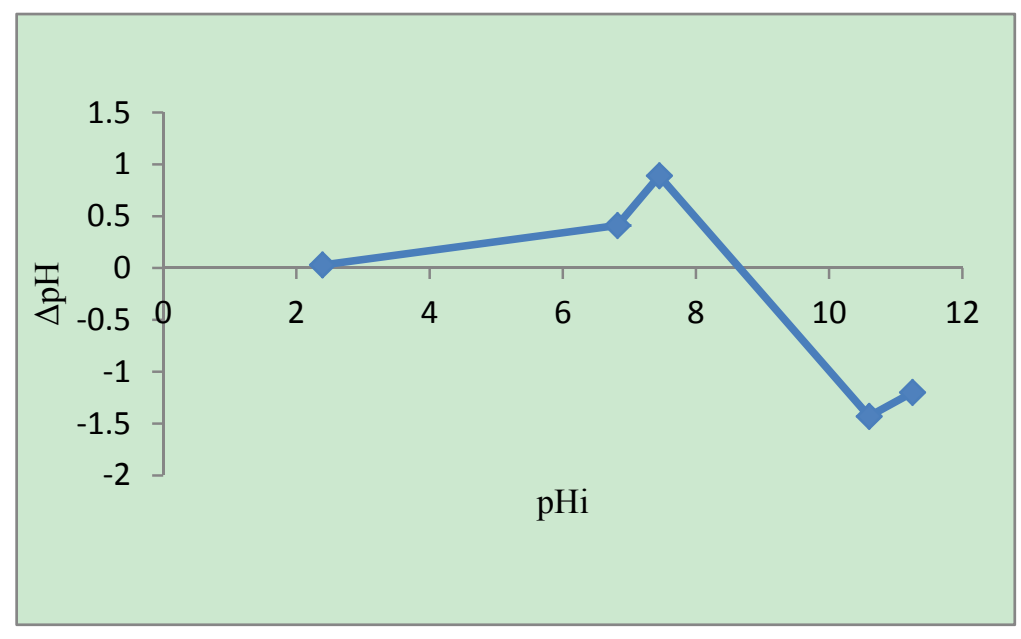

Figure 4. Point of zero charge $\left(\mathrm{pH}_{\mathrm{PZC}}\right)$

The point of zero charge being 8.7 , it means that, for a $\mathrm{pH}$ less than 8.7 , the functions groups on the surface of biosorbent are protoned by protons $\mathrm{H}^{+}$excess in the solution; the biosorbent is positively charged and become attractor of adsorbate negatively charged. On the other hand, if the $\mathrm{pH}$ of the solution is higher than 8.7, the functions groups on the surface of biosorbent are deprotoned by the presence of $\mathrm{OH}^{-}$ions in the solution. The biosorbent is negatively charged and become attractor of adsorbate positively charged (Hazourli et al., 2007).

\subsubsection{Specific Surface and Iodine Number of Adsorbents}

The BM value (VBS) has been determined from BM test. Maximal adsorption is obtained when persistent clear blue ring appear in the periphery of the stain (Figure 5). 


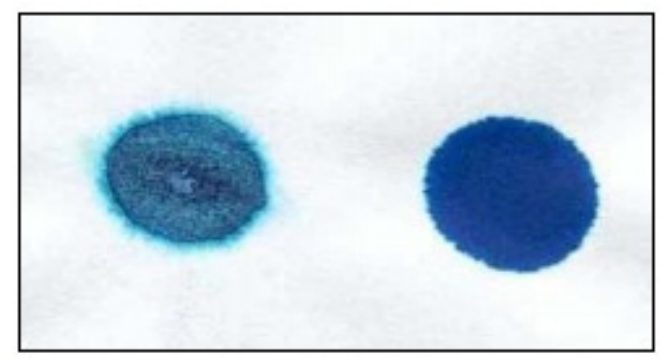

Figure 5. Blue methylene test, left: Positive test and right: Negative test

The surface developed per unit of biosorbent mass and iodine number have been determined. The table 1 presents the result.

Table 1. Specific surface and iodine number of biosorbent

\begin{tabular}{ccc}
\hline \multirow{2}{*}{ Biosorbent } & Specific surface $\left(\mathrm{m}^{2} / \mathrm{g}\right)$ & Iodine number $(\mathrm{mg} / \mathrm{g})$ \\
\cline { 2 - 3 } & $104.65 \pm 1$ & $1560.87 \pm 1$ \\
\hline
\end{tabular}

The table 1 indicates that, the specific surface of biosorbent is $104.65 \pm 1 \mathrm{~m}^{2} / \mathrm{g}$. According to (Dada et al., 2012), the specific surface of untreated rice husk is $19.8 \mathrm{~m}^{2} / \mathrm{g}$. So, specific surface of activated rice husk is 5 times those of untreated rice husk. It means that, acid treatment leads the destruction of organic matter (cellulose fiber and lignine granule) of rice husk (Hazourli et al., 2007; Faria et al., 2004), this situation confers to biosorbent a higher specific surface, more and more porous structure. This porous structure favorizes good adsorption capacity of biosorbent. The analyze of iodine number indicates that it is $1560,87 \pm 1 \mathrm{mg} / \mathrm{g}$; According to (Hazourli et al., 2007; Sun et Jiang, 2016), the iodine number being higher than $475 \pm 1 \mathrm{mg} / \mathrm{g}$, so the biosorbent surface is constitued in majority of micropores and can be used for the treatment of waste water.

\subsubsection{FTIR}

The chemical structure of the adsorbent is of vital importance in understanding the adsorption process. The FTIR technique is an important tool to identify the characteristic functional groups, which are instrumental in adsorption of pollutants. The FTIR spectra of the raw rice husk before sorption were used to determine the vibrational frequency changes in the functional groups in the adsorbent (figure 6).

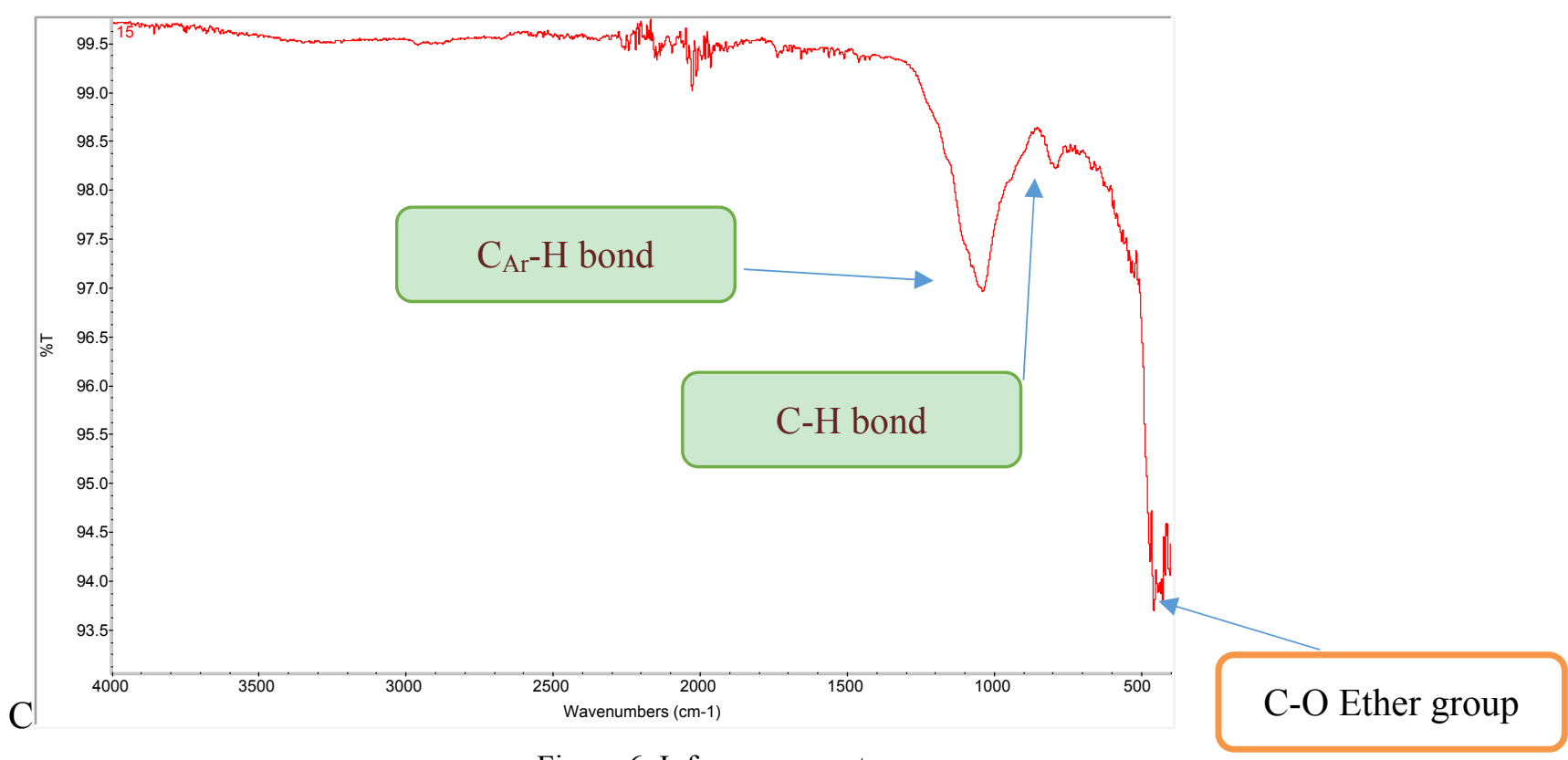

Figure 6. Infrarouge spectrum 
The key chemical groups or bonds of the biosorbent detected by Fourrier translation spectrogram were listed in table 2. It was obvious to show that, $\mathrm{C}-\mathrm{H}$ bond, $\mathrm{C}_{\mathrm{Ar}} \mathrm{H}, \mathrm{C}-\mathrm{O}$ (Ether group), was the main chemical group of the biosorbent. Accordingly, one of the most important factor that distinguish the rice husk as adsorbent for wastewater treatment among researchers is the chemical properties (Safa and Bhatti,2011; Chakraborty et al., 2011) that table 2 has showed. The effects of the presence of the surface functional group on adsorption of phenol were analyzed by observing the shifting of the FTIR peaks after the adsorption experiment. Analysis of FTIR shows that the $-\mathrm{OH}, \mathrm{C}-\mathrm{H},-\mathrm{CO}, \mathrm{C}-\mathrm{OH}, \mathrm{Si}-\mathrm{OH}$ and $-\mathrm{Si}-\mathrm{H}$ groups contribute to the adsorption of pollutants onto the surface of adsorbent. In fact The adsorption capacity was greatly influenced by surface group changes.

Table 2. Chemicals functions groups

\begin{tabular}{cc}
\hline Wave number $\left(\mathbf{c m}^{-1}\right)$ & Chemicals groups or bonds \\
\hline $403.06-466,83$ & $\mathrm{C}_{\mathrm{tet}}-\mathrm{H}$ bond \\
519,27 & $\mathrm{C}_{\mathrm{Ar}}-\mathrm{H}$ bond \\
785.61 & $\mathrm{C}-\mathrm{H}$ bond \\
1035.62 & $\mathrm{C}-\mathrm{O}$ Ether group \\
\hline
\end{tabular}

\section{Conclusion}

In this study, we showed that it is possible to produce rice husk biosorbent by phosphoric acid treatment. The specific surface of biosorbent is $104,65 \pm 1 \mathrm{~m}^{2} / \mathrm{g}$; it is 5 times than those of untreated rice husk. Iodine number being $1560,87 \pm 1 \mathrm{mg} / \mathrm{g}$, the biosorbent is constitued in majority of micropores. The acid treatment developed better porosity of biosorbent. This situation favorise a good adsorption. The band obtained in the spectrogram indicate the presence of cellulose, hemicellulose and lignin as major constituents of the rice husk. The physicochemical characteristics of the biosorbent are similar to those of activated carbon. In consequence, the valorisation of rice husk contribute to the depollution of waste water and to safeguard the environment. Finally, the rice husk's pollutants yesterday, is low cost adsorbent today and is favorable adsorber for growing country.

From both economics and environmental perspectives, these experimental results warrant further efforts, perhaps in terms of large scale manufacturing and testing.

\section{References}

AFNOR. (1996). Qualite des sols. Recueil de Normes Françaises. 3eme Edition. Paris.

Calvet, R., Terce, M., \& Arvieu, J. C. (1980). Adsorption des pesticides par les sols et leurs constituants Ann. Agron, 31, 33-385.

Chakraborty, S., Chowdhury, S., \& Saha, P. D. (2011). Adsorption of Crystal Violet from aqueous solution onto $\mathrm{NaOH}$-modified rice husk. Carbohydrate Polymers, 86, 1533-1541. https://doi.org/10.1016/j.carbpol.2011.06.058

Dada, A. O., Olalekan, A. P., Olatunya, A. M., \& Dada, O. (2012). Langmuir, Freundlich, Temkin and DubininRadushkevich Isotherms Studies of Equilibrium Sorption of $\mathrm{Zn}^{2+}$ Unto Phosphoric Acid Modified Rice Husk, IOSR. Journal of Applied Chemistry (IOSR-JAC), 3, 38-45. https://doi.org/10.9790/5736-0313845

Davila-Jimenez, M. M., Elizalde-Gonzalez, M. P., \& Hernandez Montoya, V. (2009). Performance of mango seed adsorbent in the adsorption of antrhaquinone and azo dyes in single and binary aqueous solutions. Bioresources technology, 100, 6199-6206. https://doi.org/10.1016/j.biortech.2009.06.105

Eko, M. C. (2016). Influence de la matiere minerale sur l'adsorption de la matiere organique par les biosorbants de dechets menagers (pelure de plantain et rafle de maïs). Memoire de Master specialite Chimie industrielle et Environnement: Ecole Nationale Superieure de Sciences Agro-industrielle de l’Universite de Ngaoundere, pp. 74.

Faouzia, B. (2010). Elimination des colorants cationiques par des charbons actifs synthetises à partir des residus de l'agriculture. Memoire de Magister, faculte de technologie, Universite de Ferhat ABBAS, Algerie pp. 103.

Faria, P. C. C., Orfao, J. J. M., \& Pereira, M. F. R. (2004). Adsorption of anionic and cationic dyes on activated carbons with different surface chemistry. Water Res., 38, 2043-2052. https://doi.org/10.1016/j.watres.2004.01.034 
Franca, A. S., Oliveira, L. S., Santos, P. I. A., Saldanha, S. A., \& Salum, S. A. (2008). Mango seed as biosorbent for basic dyes. Journal of Biotechnology, 10, 1517. https://doi.org/10.1016/j.jbiotec.2008.07.1518

Hazourli, S., Ziata, M., Hazourili, A., \& Cherfi, M. (2007). Valorisation d'un residu naturel ligno-cellulosique en charbon actif: Exemple des noyaux de dattes. Revue des energies renouvelables ICRESD-07 Tlemcen. 187-192.

Ho, Y. (2005). Effect of $\mathrm{pH}$ on lead removal from water using tree fern as the adsorbent. Bioresources Technology, 96, 1292-1296. https://doi.org/10.1016/j.biortech.2004.10.011

Kolwa, E. D. (2018). Yagoua mars 2018.

Kumar, K. V., \& Kumaran, A. (2005). Removal of methylene blue by mango seed kernel powder. Biochemical Engineering Journal, 25, 83-93. https://doi.org/10.1016/j.bej.2005.08.004

Mouthe, A. G. (2017). Etude physico-chimique de l'adsorption du cristal violet par le biosorbant et le charbon actif des amandes de mangue. These de doctorat, specialite Chimie industrielle et Environnement: Ecole Nationale Superieure de Sciences Agro-industrielle de l'Universite de Ngaoundere, pp. 204.

Özacar, M., \& Sengil, I. A. (2005). Adsorption of metal complex dyes from aqueous solution by pine sawdust. Bioresources Technology, 96, 791-795. https://doi.org/10.1016/j.biortech.2004.07.011

Saeed, A., Sharif, M., \& Iqbal, M. (2010). Application potential of grapefruit peel as dye sorbent: Kinetics, equilibrium and mechanism of Crystal Violet adsorption. Journal of Hazardous Materials, 179(1-3), 564572. https://doi.org/10.1016/j.jhazmat.2010.03.041

Safa, Y., \& Bhatti, H. N. (2011). Adsorptive removal of direct dyes by low cost rice husk: Effect of treatments and modifications. African Journal of Biotechnology, 10(16), 3128-3142. https://doi.org/10.5897/AJB10.1302

Tchuifon Tchuifon, D. R., Anagho, S. G., Ketcha, J. M., Ndifor Angwafor, N. G., \& Ndi, J. N. (2014). Kinetics and equilibrium studies of adsorption of phenol in aqueous solution onto activated carbon prepared from rice and coffee husks. International Journal of Engineering and Technical Research, 2(10), 166-173.

\section{Copyrights}

Copyright for this article is retained by the author(s), with first publication rights granted to the journal.

This is an open-access article distributed under the terms and conditions of the Creative Commons Attribution license (http://creativecommons.org/licenses/by/4.0/). 